\title{
CAREGIVING BURDEN AND COPING STRATEGIES OF CAREGIVERS CARING FOR ELDERLY WITH END STAGE RENAL DISEASE \\ Laila Salama Elkafrawy ${ }^{1}$, Eman Hassan Mounir ${ }^{2}$, Mohammed Kamal Emad Eldin $^{3}$, and Soad Hassan Abd Elhameed ${ }^{4}$ \\ (1) Demonstrator of Gerontological Nursing -Faculty of Nursing-Mansoura University \\ (2) Lecturer of Gerontological Nursing -Faculty of Nursing- Mansoura University \\ (3) Lecturer of Nephrology- Faculty of Medicine- Mansoura University \\ (4) Assist. Prof. of Gerontological Nursing - Faculty of Nursing-Mansoura University, Egypt
}

\begin{abstract}
Background: End stage renal disease affects all aspects of life of the patients and their caregivers. Caregivers receive little support than patients for that, coping strategies are important to solve difficult situation and cope with burden. Aim: Assess caregiving burden and coping strategies of caregivers caring for elderly with end stage renal disease. Design: A descriptive research design was used in this study. Setting: This study was conducted at hemodialysis unit in Mansoura University Hospital. Subjects: A purposive sample of 150 caregivers who met the inclusion criteria. Tools: Three tools were utilized in this study; Structured interview schedule, Zarit burden interview and Jaloweic coping scale. Results: $44.0 \%$ of the studied caregivers had moderate level of burden. The mean of affective oriented coping strategies was $25.49 \pm 7.77$ while, the mean of problem oriented coping strategies was $25.42 \pm 8$.30.There was negative significant correlation between caregiver burden and using of affective oriented and problem oriented coping strategies $\left(\mathrm{p}=0.01^{*} \&\right.$ $\mathrm{p}=0.004^{*}$ respectively). Conclusion: The caregivers' burden is common among family caregivers who care for elderly patients with end stage renal disease undergoing hemodialysis. Caregivers have been found to be using affective oriented coping strategies more than problem oriented coping strategies.
\end{abstract}

Key words: Caregiver burden, Elderly, End stage renal disease.

\section{Introduction}

Chronic kidney disease (CKD) is an emerging global public health problem. CKD has shifted from the 36th cause of death in 1990 to the 19 th cause in $2013^{[1]}$. Worldwide, the prevalence of end stage renal disease (ESRD) differs greatly. End stage renal disease is one of the main health problems in Egypt. In Egypt, the last statistics was performed, the prevalence was 483 patients per million. In the El-Minia governorate, one of the Upper Egypt governorates, the prevalence was 308 patients per million ${ }^{[2]}$.In Dakahlia governorate the prevalence rate of ESRD was 619.3 PMP during year 2014 when the total population was 5.7 million ${ }^{[3]}$.

Currently, hemodialysis represents the main mode for treatment. The prevalence of dialysis patients has increased from 225 patients per million in 1996 to 483 patients per million in 2008 ${ }^{[3]}$. Hemodialysis (HD) is the routine renal replacement therapy (RRT) for restoring the body's internal environment and homeostasis ${ }^{[4]}$. Hemodialysis is a source of stress, cause problems such as social isolation, loss of employment, dependence on social security and reduction in physical activity. These problems can 
trigger a stress reaction in the individual. The individual and family alike can use coping strategies to control the stress ${ }^{[5]}$.

With the rapid rise in number of elderly patients with ESRD and those with comorbid conditions receiving renal replacement therapies, combined with the increasing demands of the 21 st century, burden on the caregivers have increased even more than in the past days. These caregivers not only have to sustain their living and maintain their quality of life, they also have to take care of their chronically ill family member. Moreover, as the chronic kidney disease patients are usually middle to old aged adults, their caregivers are equally aged partners, many of whom have their own physical ailments, lack community connections, and have limited financial reserves ${ }^{[6]}$.Caregivers are people who have the great amount of involvement in elderly patients assistance and care along the disease course to manage and adapt the elderly patients. Family of elderly patients who have end stage renal disease must perform support and care in outpatient centers or at home, as hemodialysis unit of hospital. This may affect mental health of caregiver to varying degrees ${ }^{[7]}$.

Elderly Patient with ESRD often depend on informal caregiver to help them with their medical needs and activities of daily living. Duties taken on by informal caregiver can involve medications administration, transportation to dialysis and other medical appointment, personal hygiene maintenance, meals provision, etc. different from paid caregiver, informal caregiver is typically family members or friends, who also give day-to-day psychosocial and emotional support ${ }^{[8]}$.

End stage renal disease affects almost all aspects of life of the patients and their caregivers. The caregiver role is stressful and demanding but is often neglected, especially in developing countries ${ }^{[6]}$.Caregiver usually take less attention while the most focus is on the elderly patients. Recurrent hospitalization of the elderly patient and factor associated with the disease may cause the depression deterioration and caregiver's quality of life reduction ${ }^{[7]}$.

Coping strategies play an important role in resolving difficult conflict situations that may arise in various aspects of life ${ }^{[9]}$. The coping strategies refer to the specific efforts, both behavioral and psychological that people employ to overcome difficult situations and to adapt to existing circumstances. People use certain strategies to cope with stress ${ }^{[10]}$.

\section{Significance of the study}

End stage renal disease is one of the major health problems in Egypt. In Egypt ESRD prevalence has risen from 403 per million populations (PMP) at year 2003 to 483 PMP at year 2004. ESRD has shifted from the 36th cause of death in 1990 to the 19th cause in 2013.Elderly patients with ESRD often rely on unpaid caregivers to assist them with their daily living and medical needs. Caregivers often receive little attention and the main focus is on the patients. Frequent hospitalizations of the elderly patients and side effects during hemodialysis can lead to the deterioration of depression and reduction of caregiver's quality of life. Caregivers use different coping strategies to decrease their burden and solve difficult situations and stresses that may appear in different life aspects.

Therefore, assessment of caregiving burden and coping strategies of caregivers caring for elderly with end stage renal disease are very important.

\section{Aim of the study}

The aim of this study was to assess caregiving burden and coping strategies of caregivers caring for elderly with end stage renal disease. 
Research questions:-

Q1: What is the caregiving burden of caregivers caring for elderly with end stage renal disease?

Q2: What are the coping strategies of caregivers caring for elderly with end stage renal disease?

\section{Subjects \& method}

\section{Research design:}

A descriptive research design was used in this study.

\section{The study setting :}

This study was carried out in hemodialysis unit located in the first floor inside medical department 3 in Mansoura University Hospital which contains 23 beds connected with dialysis machines.

Subjects of the study:

A purposive sample of 150 family caregivers of the older adults diagnosed with end stage renal disease on hemodialysis attending the above mentioned settings.

- Inclusion criteria:

- Aged 18 years and more

- Responsible for providing care for the elderly patients included in the study

- Accept to participate in the study

- Able to communicate

- Available at the time of data collection

- Exclusion criteria:

- Paid caregivers

- Caregivers who are the first time caring of the older adult

- Caregivers who have handicap

Tool of data collection-:

In order to collect the necessary information for the study, three tools were used:

Tool I: Structured Interview Schedule: It was developed by the researcher after literature reviewing and included two parts: Part I: Data about elderly patients. It included items related to; 1-Demographic characteristics of the elderly patients such as age, sex, social status, level of education, occupation, and income, 2-Medical history, such as suffering from other disease, medication taken and compliance on medications, 3History of disease: duration of end stage renal disease, received hemodialysis and presence of side effect during hemodialysis. Part II: Data about elderly's family caregiver. It included items related to; 1-Demographic characteristics of the family caregiver such as age, sex, level of education, occupation, relation to elderly, social status, and income, 2-Medical history of the family caregiver; it include type of disease such as cardiovascular diseases, hypertension, diabetes mellitus and medication used.

Tool II: Zarit Burden Interview: was developed by Zarit et al. (1980) ${ }^{[11]}$. Twenty two items rating scale measuring caregiving burden. It was translated into Arabic and was approved for validity and reliability by Magdy (Magdy, 2015) ${ }^{[12]}$; it indicated that the scale has reliability of 0.85 . Response options range from 0 (Never) to 4 (Nearly Always). Scoring key: little or no burden $=0$ to 20 ; mild to moderate burden $=21$ to 40 ; moderate to severe burden $=41$ to 60 ; severe burden $=61$ to $88^{[11]}$.

Tool III: Jaloweic Coping Scale: was developed by Jaloweic and Power in 1981. Jaloweic coping scale was used to identify coping behaviors of caregivers caring for elderly patients with different chronic diseases. Jaloweic coping scale was translated into Arabic and used by Abd El Meguid (Abd El Meguid, 2000) [13] and was approved for validity and reliability by (Fadila, 2007) [14], it indicated that the scale has reliability of 0.78. Jaloweic coping scale consists of 40 items, classified into 15 problem-oriented coping behaviors, and 25 affectiveoriented behaviors. The scale uses 5-point 
Likert scale with response options of always (4), often (3), about half the time (2), occasionally (1), and never (0). The higher score indicates greater use of particular coping behavior ${ }^{[15]}$.

\section{Sample size:}

Calculating sample size through DSS research sample size calculator software, at $5 \% \propto$ error $(95.0 \%$ significance) and $20.0 \beta$ error $(80.0 \%$ power of the study), assuming the mean burden is $30.41 \pm 12.065^{[16]}$ compared to be in average in our community 33.0. The calculated sample size was 134 by adding $10.0 \%$ for better quality of data collection. So, the study sample was 150 caregivers.

\section{Method}

\section{Results:}

Table (1): shows the age of the studied elderly ranged from 60 to 78 years with a mean of $(65.23 \pm 4.90$ years $) .78 \%$ of them aged from 60years to less than 70 years. Females were more prevalent $(53.3 \%)$ of the elderly, $64 \%$ were married. More than half $(50.7 \%)$ were residing in rural areas. In relation to the economic status, $62.6 \%$ reported that their income was not enough. $44 \%$ were illiterate. Regarding elderly patients occupation before retirement, it was observed that $51.30 \%$ were not working before retirement and $78 \%$ of studied elderly were having pension. More than three fifth (64\%) of studied subjects were living with their wife/husband.

Table (2): demonstrates that, the duration of dialysis varied according to the duration of disease $32 \%$ of studied elderly patients started dialysis for less than 3 years. All of the studied subjects make dialysis three sessions per week and the duration of each session lasts 4 hours among $75 \%$ of the studied subjects.

Table (3): shows that the age of the studied caregivers ranged from 19 to 65 years with mean \pm SD age $40.17 \pm 12.66$ years. $40.7 \%$ of the studied caregivers were 30 to less than 45 years, $82 \%$ were female, $85.3 \%$ were married and $36.7 \%$ had secondary education. Regarding caregivers occupation, it was observed that more than two third $(66 \%)$ were not working. In relation to the economic status, about the half $(49.3 \%)$ reported that their income was enough.

Table (4): shows that more than one third $(38 \%)$ of the studied caregivers were son or daughter, $77.3 \%$ of the studied caregivers living with elderly patients, more than half $(56.0 \%)$ of the studied caregivers were primary caregivers and about $36.4 \%$ from secondary caregivers were son or daughter. Period of caregiving ranged from 0.1 to 15 years, more than one third $(35.3 \%)$ were caring since 1 to less than 3 years. Daily hours of caring ranged from 2 to 20 hours, more than half $(55.3 \%)$ of the studied caregivers spend 8 hours and above daily caring the elderly patients. The majority of studied caregiver's education $(94.0 \%)$ didn't relate to elderly care and $99.3 \%$ didn't receive training for elderly care.

Figure (1): shows that more than two fifth $(44.0 \%)$ of the studied caregivers had moderate level of burden and only $3.3 \%$ had severe burden.

Table (5): shows that the statement that denotes (hope that things will get better) had the higher mean score $3.36 \pm$ 0.71 , followed by (pray, trust in God) 2.73 \pm 1.09 . On the other hand, the less frequently used affective oriented coping strategies was (drink alcoholic beverages, followed by (take drugs) had mean score of $0.07 \pm 0.29$.

Table (6): shows that the statement that denotes (Talk the problem over with someone who has been in the same type of situation) had the higher mean score 3.23 \pm 0.96 . (Draw on past experience to help you handle the situation) had mean score 
of $3.26 \pm 0.80$. On the other hand, the less frequently used problem oriented coping strategies was (Do anything just to do something) with mean of $0.43 \pm 0.73$, followed by (Let someone else solve the problem) had mean score of $0.55 \pm 0.82$.

Figure (2): shows that there was a statistically significant negative correlation between caregiver burden and using of affective oriented and problem oriented coping behaviors $(\mathrm{p}=0.01 * \& \mathrm{p}=0.004 *$ respectively).

Table 1: Demographic characteristics of the elderly patients with end stage renal disease

\begin{tabular}{|c|c|c|}
\hline Items & $N=150$ & $\%$ \\
\hline \multicolumn{3}{|l|}{ Age (years) } \\
\hline$-60-$ & 69 & 46.0 \\
\hline$-65-$ & 48 & 32.0 \\
\hline$-70-$ & 28 & 18.7 \\
\hline$-75+$ & 5 & 3.3 \\
\hline \multicolumn{3}{|c|}{$\begin{array}{c}\text { Range: } 60.0-78.0 \text { years, } \quad \text { Mean } \pm \mathrm{SD}=65.23 \\
\pm 4.90 \text { years }\end{array}$} \\
\hline \multicolumn{3}{|l|}{ Sex } \\
\hline - Males & 70 & 46.7 \\
\hline - Females & 80 & 53.3 \\
\hline \multicolumn{3}{|l|}{ Residence } \\
\hline - Rural & 76 & 50.7 \\
\hline - Urban & 74 & 49.3 \\
\hline \multicolumn{3}{|l|}{ Social status } \\
\hline - Married & 96 & 64.0 \\
\hline - Widow & 49 & 32.7 \\
\hline - Divorced & 5 & 3.3 \\
\hline \multicolumn{3}{|l|}{ Education } \\
\hline - Illiterate & 66 & 44.0 \\
\hline - Read and write & 32 & 21.4 \\
\hline - Secondary & 29 & 19.3 \\
\hline - University & 21 & 14.0 \\
\hline - Postgraduate & 2 & 1.3 \\
\hline \multicolumn{3}{|l|}{ Work before retirement } \\
\hline - Working & 73 & 48.7 \\
\hline - Not working & 77 & 51.3 \\
\hline \multicolumn{3}{|l|}{ Income } \\
\hline - Not Enough & 94 & 62.6 \\
\hline - Enough & 52 & 34.7 \\
\hline - Enough \& save & 4 & 2.7 \\
\hline \multicolumn{3}{|l|}{ Source of Income } \\
\hline Pension & 117 & 78.0 \\
\hline Relatives & 16 & 10.7 \\
\hline - Social affairs & 15 & 10.0 \\
\hline - Others & 2 & 1.3 \\
\hline \multicolumn{3}{|l|}{ Living with whom } \\
\hline - Wife / husbands & 96 & 64.0 \\
\hline - Siblings & 46 & 30.6 \\
\hline - Alone & 4 & 2.7 \\
\hline - Relatives & 4 & 2.7 \\
\hline
\end{tabular}

Table2:Medical history of elderly patients with end stage renal disease

\begin{tabular}{|c|c|c|}
\hline Items & $N=(150)$ & $\%$ \\
\hline $\begin{array}{c}\text { Duration of disease } \\
\quad<3 \text { years } \\
-\quad 3-<5 \text { years } \\
-\quad 5-<10 \text { years } \\
-\quad \geq 10 \text { years }\end{array}$ & $\begin{array}{l}48 \\
33 \\
35 \\
34\end{array}$ & $\begin{array}{l}32.0 \\
22.0 \\
23.3 \\
22.7\end{array}$ \\
\hline $\begin{array}{c}\text { Duration of dialysis } \\
-\quad<3 \text { years } \\
-\quad 3-<5 \text { years } \\
-\quad 5-<10 \text { years } \\
-\quad \geq 10 \text { years }\end{array}$ & $\begin{array}{l}48 \\
33 \\
35 \\
34\end{array}$ & $\begin{array}{l}32.0 \\
22.0 \\
23.3 \\
22.7\end{array}$ \\
\hline $\begin{array}{l}\text { Number of session per week } \\
\text { - Three }\end{array}$ & 150 & 100.0 \\
\hline $\begin{array}{l}\text { Duration of session } \\
-\quad 3 \text { hours } \\
-\quad 4 \text { hours }\end{array}$ & $\begin{array}{c}36 \\
114\end{array}$ & $\begin{array}{l}24.0 \\
76.0\end{array}$ \\
\hline
\end{tabular}

Table 3: Distribution of the studied family caregivers according to their demographic characteristics

\begin{tabular}{|c|c|c|}
\hline Items & $\mathbf{N}=\mathbf{1 5 0}$ & $\%$ \\
\hline \multicolumn{3}{|l|}{ Age (years) } \\
\hline$-18-$ & 30 & 20.0 \\
\hline$-30-$ & 61 & 40.7 \\
\hline$-45+$ & 59 & 39.3 \\
\hline \multicolumn{3}{|c|}{ Range: $\begin{array}{c}19.0-65.0 \text { years, Mean } \pm S D=40.17 \\
\pm 12.66 \text { years }\end{array}$} \\
\hline \multicolumn{3}{|l|}{ Sex } \\
\hline - Males & 27 & 18.0 \\
\hline - Females & 123 & 82.0 \\
\hline \multicolumn{3}{|l|}{ Social status } \\
\hline - Married & 128 & 85.3 \\
\hline - Single & 15 & 10.0 \\
\hline - Widow & 4 & 2.7 \\
\hline - Divorced & 3 & 2.0 \\
\hline \multicolumn{3}{|l|}{ Education } \\
\hline - Illiterate & 31 & 20.7 \\
\hline - Read and write & 20 & 13.3 \\
\hline - Secondary & 55 & 36.6 \\
\hline - University & 43 & 28.7 \\
\hline - Postgraduate & 1 & 0.7 \\
\hline \multicolumn{3}{|l|}{ Job } \\
\hline - Not working & 99 & 66.0 \\
\hline - Employee & 44 & 29.3 \\
\hline $\begin{array}{l}\text { - Professional } \\
\text { employee (Doctors } \\
\text { + nurses) }\end{array}$ & 7 & 4.7 \\
\hline \multicolumn{3}{|l|}{ Income } \\
\hline - Not Enough & 49 & 32.7 \\
\hline - Enough & 74 & 49.3 \\
\hline - Enough \& save & 27 & 18.0 \\
\hline
\end{tabular}


(4): Distribution of the studied family caregivers according to their caregiving properties

\begin{tabular}{|c|c|c|}
\hline Items & $N=150$ & $\%$ \\
\hline $\begin{array}{l}\text { Relation with the elderly } \\
\text { Sons/ Daughters } \\
\text { Husbands \% wife } \\
\text { - Son wife } \\
\text { - Sisters }\end{array}$ & $\begin{array}{l}57 \\
45 \\
37 \\
11\end{array}$ & $\begin{array}{l}38.0 \\
30.0 \\
24.7 \\
7.3\end{array}$ \\
\hline $\begin{array}{l}\text { Living with the elderly } \\
- \text { Yes } \\
- \text { No }\end{array}$ & $\begin{array}{c}116 \\
34\end{array}$ & $\begin{array}{l}77.3 \\
22.7\end{array}$ \\
\hline $\begin{array}{l}\text { Secondary caregivers } \\
- \text { Yes } \\
- \text { No }\end{array}$ & $\begin{array}{l}66 \\
84\end{array}$ & $\begin{array}{l}44.0 \\
56.0\end{array}$ \\
\hline $\begin{array}{l}\text { Secondary caregiver } \\
\text { relation } \\
\text { - Son /daughter } \\
\text { - Son wife } \\
\text { - Husband/wife } \\
\text { - Bother/sister } \\
\text { - Grand child }\end{array}$ & $\begin{array}{c}\mathbf{N}=(\mathbf{6 6}) \\
24 \\
22 \\
16 \\
2 \\
2\end{array}$ & $\begin{array}{l}36.4 \\
33.3 \\
24.3 \\
3.0 \\
3.0\end{array}$ \\
\hline $\begin{array}{l}\text { Period of caregiving } \\
-\quad<3 \text { years } \\
-\quad 3-<5 \text { years } \\
-\quad 5-<10 \text { years } \\
-\quad>10 \text { years }\end{array}$ & $\begin{array}{l}53 \\
40 \\
41 \\
16\end{array}$ & $\begin{array}{l}35.3 \\
26.7 \\
27.3 \\
10.7\end{array}$ \\
\hline \multicolumn{3}{|c|}{ Range: $0.1-15$ years, Mean $\pm S D=4.75 \pm 3.24$} \\
\hline $\begin{array}{l}\text { Caregiving hours } \\
-\quad 2-<5 \text { hours } \\
-5-<8 \text { hours } \\
-\quad \geq 8 \text { hours }\end{array}$ & $\begin{array}{l}24 \\
43 \\
83\end{array}$ & $\begin{array}{l}16.0 \\
28.7 \\
55.3\end{array}$ \\
\hline \multicolumn{3}{|c|}{$\begin{array}{c}\text { Range: } 2.0-20.0 \text { hours, Mean } \pm S D=8.55 \pm \\
3.94 \text { hours }\end{array}$} \\
\hline $\begin{array}{lll}\text { Education } & \text { related } & \text { to } \\
\text { elderly care } & & \\
- \text { Yes } & \\
- \text { No } & \end{array}$ & $\begin{array}{c}9 \\
141\end{array}$ & $\begin{array}{c}6.0 \\
94.0\end{array}$ \\
\hline $\begin{array}{l}\text { Training for elderly care } \\
- \text { Yes } \\
- \text { No }\end{array}$ & $\begin{array}{c}1 \\
149\end{array}$ & $\begin{array}{c}0.7 \\
99.3\end{array}$ \\
\hline
\end{tabular}

Figure(1):Level of burden among caregivers of elderly patients with end stage renal disease

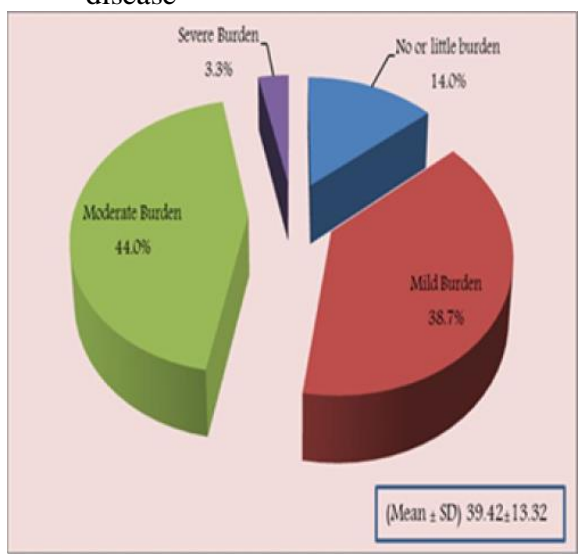

Figure (1): level of burden among caregivers of elderly with end stage renal disease
Table (5): Distribution of the studied caregivers according to affectiveoriented coping behaviors

\begin{tabular}{|c|c|}
\hline Coping behaviors & Mean + SD \\
\hline Affective oriented behavior & Mean $\pm \mathrm{SD}$ \\
\hline $\begin{array}{l}\text { 1-Hope that things will get } \\
\text { better. }\end{array}$ & $3.36 \pm 0.71$ \\
\hline 2- Eat, smoke, and chew gum. & $1.01 \pm 1.15$ \\
\hline 3- Pray, trust in God. & $2.73 \pm 1.09$ \\
\hline 4-Get nervous & $1.363 \pm 1.23$ \\
\hline 5- Worry. & $0.73 \pm 0.97$ \\
\hline 6- Want to be alone. & $0.77 \pm 0.94$ \\
\hline $\begin{array}{l}\text { 7- Laugh it off, figuring that } \\
\text { things could be worse }\end{array}$ & $0.319 \pm 0.46$ \\
\hline $\begin{array}{l}\text { 8- Try to put the problem out of } \\
\text { your mind. }\end{array}$ & $1.318 \pm 1.01$ \\
\hline 9- Daydream, fantasizes. & $0.16 \pm 0.48$ \\
\hline $\begin{array}{l}\text { 10- Get prepared to expect the } \\
\text { worst. }\end{array}$ & $0.66 \pm 0.72$ \\
\hline 11- Get mad; curse; swear. & $0.58 \pm 0.87$ \\
\hline 12- Cry; get depressed. & $1.22 \pm 1.10$ \\
\hline $\begin{array}{l}\text { 13-Go to sleep, figuring things } \\
\text { will look better in the morning }\end{array}$ & $0.62 \pm 0.74$ \\
\hline $\begin{array}{l}\text { 14-Don't worry about it; } \\
\text { everything will probably work } \\
\text { out fine. }\end{array}$ & $1.06 \pm 0.90$ \\
\hline $\begin{array}{l}\text { 15-Work off tension with } \\
\text { physical activity. }\end{array}$ & $0.45 \pm 0.89$ \\
\hline $\begin{array}{l}\text { 16-Take out your tension on } \\
\text { someone or something else. }\end{array}$ & $1.15 \pm 0.95$ \\
\hline 17-Drink alcoholic beverages. & $0.00 \pm 0.00$ \\
\hline $\begin{array}{l}\text { 18-Resign yourself to the } \\
\text { situation because things look } \\
\text { hopeless }\end{array}$ & $0.89 \pm 0.92$ \\
\hline $\begin{array}{l}\text { 19-Do nothing in the hope that } \\
\text { the problem will take care of } \\
\text { itself. }\end{array}$ & $1.25 \pm 0.92$ \\
\hline $\begin{array}{l}\text { 20-Resign yourself to the } \\
\text { situation because it's your fate }\end{array}$ & $2.315 \pm 0.71$ \\
\hline $\begin{array}{l}\text { 21-Blame someone else for your } \\
\text { problem. }\end{array}$ & $0.20 \pm 0.42$ \\
\hline $\begin{array}{l}22-\text { Meditation, } \\
\text { biofeedback. }\end{array}$ & $0.33 \pm 0.58$ \\
\hline 23-Take drugs. & $0.07 \pm 0.29$ \\
\hline $\begin{array}{l}\text { 24-Seek comfort or help from } \\
\text { family or friends. }\end{array}$ & $2.361 \pm 0.97$ \\
\hline 25- Withdraw from the situation & $0.83 \pm 0.92$ \\
\hline $\begin{array}{c}\text { Total Score of Affective oriented } \\
\text { coping behaviors }\end{array}$ & $25.49 \pm 7.77$ \\
\hline
\end{tabular}


Table(6): Distribution of the studied caregivers according to problem oriented coping behaviors

\begin{tabular}{|c|c|}
\hline Coping behaviors & \\
\hline $\begin{array}{l}\text { problem oriented coping } \\
\text { behavior }\end{array}$ & Mean \pm SD \\
\hline $\begin{array}{l}\text { 1- Try to maintain some control } \\
\text { over the situation. }\end{array}$ & $1.59 \pm 0.87$ \\
\hline $\begin{array}{l}\text { 2- Find out more about the } \\
\text { situation so you can handle it } \\
\text { better. }\end{array}$ & $1.61 \pm 0.95$ \\
\hline $\begin{array}{l}\text { 3- Think through different ways } \\
\text { to handle the situation }\end{array}$ & $2.09 \pm 0.99$ \\
\hline $\begin{array}{l}\text { 4- Look at the problem } \\
\text { objectively }\end{array}$ & $1.26 \pm 0.94$ \\
\hline $\begin{array}{l}5 \text { Try out different ways of } \\
\text { solving the problem to see } \\
\text { which works the best. }\end{array}$ & $2.23 \pm 0.96$ \\
\hline $\begin{array}{l}\text { 6- Draw on past experience to } \\
\text { help you handle the situation }\end{array}$ & $3.26 \pm 0.80$ \\
\hline $\begin{array}{l}\text { 7- Try to find meaning in the } \\
\text { situation }\end{array}$ & $1.34 \pm 0.98$ \\
\hline $\begin{array}{l}\text { 8- Break the problem down into } \\
\text { "smaller pieces". }\end{array}$ & $1.52 \pm 0.94$ \\
\hline $\begin{array}{l}\text { 9- Set specific goals to help } \\
\text { solve the problem. }\end{array}$ & $1.26 \pm 1.03$ \\
\hline 10- Accept the situation as it is & $1.85 \pm 0.96$ \\
\hline $\begin{array}{l}\text { 11- Talk the problem over with } \\
\text { someone who has been in } \\
\text { the same type of situation. }\end{array}$ & $3.23 \pm 0.96$ \\
\hline $\begin{array}{l}\text { 12- Actively try to change the } \\
\text { situation }\end{array}$ & $1.61 \pm 0.96$ \\
\hline $\begin{array}{l}\text { 13- Settle for the next best } \\
\text { thing. }\end{array}$ & $1.59 \pm 0.77$ \\
\hline $\begin{array}{l}\text { 14- Do anything just to do } \\
\text { something. }\end{array}$ & $0.43 \pm 0.73$ \\
\hline $\begin{array}{l}\text { 15- Let someone else solve the } \\
\text { problem. }\end{array}$ & $0.55 \pm 0.82$ \\
\hline $\begin{array}{l}\text { Total Score of Problem } \\
\text { oriented coping behaviors }\end{array}$ & $25.42 \pm 8.30$ \\
\hline
\end{tabular}

Figure(2a):The correlation between affective Oriented coping behaviors and caregiver burden

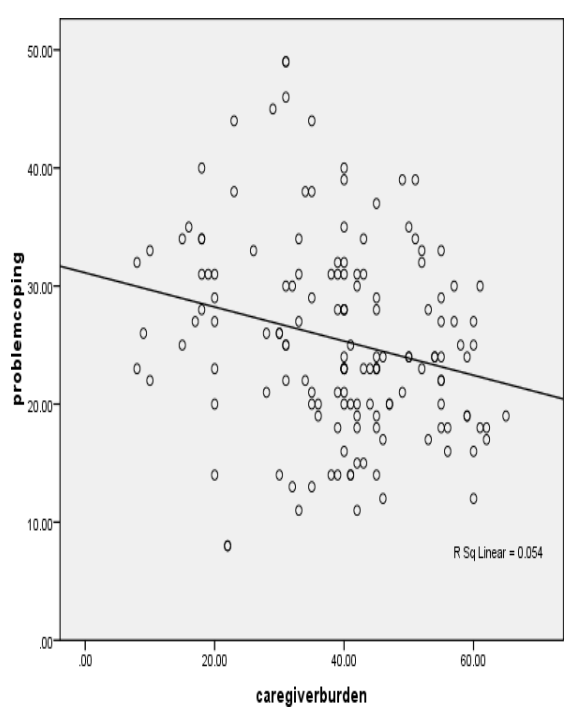

Figure(2b): The correlation between problem Oriented coping behaviors and caregiver burden

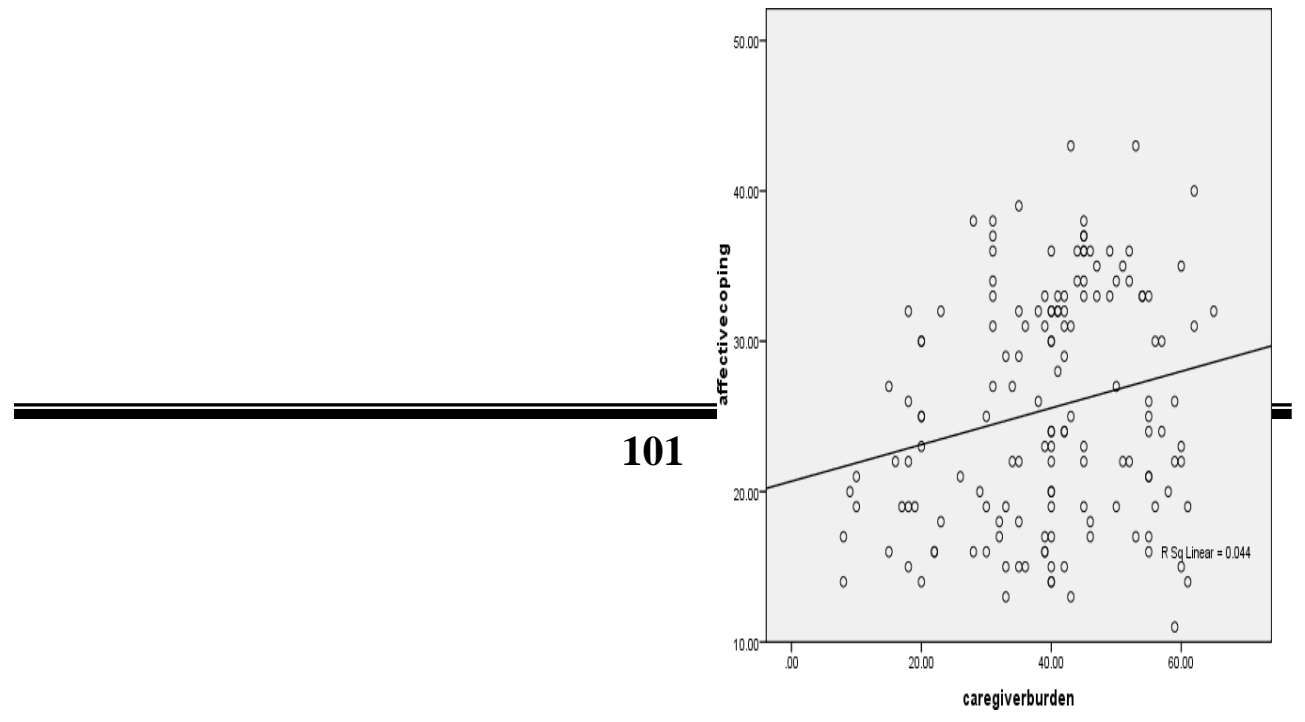




\section{Discussion:}

Chronic renal failure is a disease that is difficult to treat and affects both patients and families negatively in psychological, social and economic terms ${ }^{[17]}$. The amount of caregiving required by elderly patients with ESRD may increase family caregiver's responsibilities and make them vulnerable to emotional, physical and psychological stress. Moreover, caregivers cope with such stressors by different coping strategies; these coping strategies may be problemfocused or emotion-focused coping strategies ${ }^{[18]}$. Therefore, the aim of the present study was to assess caregiving burden and coping strategies of caregivers caring for elderly with end stage renal disease.

This study includes 150 end stage renal disease elderly patients on hemodialysis. The demographic background of the present study showed that, the mean age of the studied elderly was $65.23 \pm 4.90$ years and more than three quadrants of the elderly patient's age are between 60 to less than 70 years old. Females were more than half of the older adults. This result supported by a study done in Egypt by Abdallah, Baki, Hakim \& kamel (2014) ${ }^{[19]}$ who reported that more than half were females. The predominance of female patients is probably due to more life expectancy in females than males (Abdallah et al., 2014) ${ }^{[19]}$. More than half were residing in rural areas. This may be due to people living in rural areas are less able to maintain healthy life style and do not have access to high quality prevention, early detection, and treatment services in which there is limited access to health care. This finding in line with Abd Rabouh (2015) ${ }^{[20]}$ in Egypt and Stanifer et al., $2014^{[21]}$ who found that ESRD more prelevant in rural area than urban area. This finding not agree with a study done in Egypt by El Shahed, Sharf, El Sebaee \& Roshdy (2013) ${ }^{[22]}$ who reported that about two third of their studied patients were living in an urban area.

Concerning the level of education of the elderly patients in this study slightly more than two fifth were illiterate. This finding agree with Mogharab et al. (2011) ${ }^{[23]}$ in Iran who reported that most of studied subjects were illiterate and primary education. About more than half of the studied elderly patients were not work. This result may be related to that, females were more relevant in this study and they were house wives. This in accordance with study in Egypt by ElArbagy, Kora, El-Barbary, Gabr \& Selim (2015) ${ }^{[24]}$ who reported that more than two fifth of studied subjects didn't work. Moreover slightly more than three fifth have not enough income. This result may be due to physical consequences and side effects of hemodialysis that affects their ability to keep their job and treatment and transportation costs. This result is supported by Abd Elhafeez (2014) ${ }^{[25]}$ in Egypt who reported that more than half have financial problems.

The normal schedule range of hemodialysis sessions is between 2-3 sessions per week. Current study revealed that, all of the studied subjects made dialysis three sessions per week and three quarter of the studied patients were lasting 4 hours per session. These results may be justified as, to decrease the amounts of salt and water retention between dialysis sessions, and to decrease the rate of fluid removal and control of fluid status and blood pressure (BP). This supported by a study done in Egypt by El-Arbagy et al., (2015) ${ }^{[24]}$ who reported that, frequency of 
dialysis was 3 per week for 4 hours each session.

The current study revealed that the age of the studied caregivers ranged from 19 to 65 years. These results point toward the fact that caregiving responsibilities more often assigned to middle age groups. This supported by a study done in Egypt by Magdy (2015) ${ }^{[12]}$. The current study found that female subjects constituted more than three quarter of caregivers. This finding attributed to that females take care of family members. This is in line with a study reported that more than half of subjects were female by Oyegbile \& Brysiewicz (2017) [26] in South-West Nigeria.

This study found that more than two fifth of the studied caregivers had moderate level of burden. This result may be justified by despite of caregiving being a satisfying experience some times in our culture it is still emotionally draining, physically demanding and distracting the caregiver from taking care of self. Also, in Egypt there are limited social services and respite centers along with poor health delivery system. This is not in line with (Oyegbile \& Brysiewicz, 2017) ${ }^{[26]}$ in South-West Nigeria who reported that more than one third of participants and Salama \&Abou El-Soud (2012) ${ }^{[27]}$ in Egypt reported that more than three fifth of caregivers indicated a severe burden. And three fifth of participants reported no caregiver burden in Thailand by (Chindaprasirt et al., 2014) ${ }^{[28]}$. These differences can partly be explained by sampling variations regarding the stage of illness, the lack of availability of support care services and social networks or cultural differences which may aggravate such differences. In Egyptian society, family caregivers play a main role in the treatment of elderly patients with ESRD because of the cultural obligations.
The caregivers respond to physical and psychosocial stressors by using different coping behaviors. Coping takes two major forms problem-focused coping and emotion-focused coping strategies [18] ${ }^{[29]}$. The present study indicated a tendency among caregivers to use affective oriented coping more than problem oriented coping strategies. It can be explained by the fact that the Arab people in general and especially the Egyptian tend to use emotion and get closer to God, especially in the presence of problems.

The most frequently used affective oriented coping strategies, wish that problems will be solved, pray and trust in God and search for help and comfort from friends and family. While speak with someone who has the same problem and draw on previous experience to aid you dealing with the problem were the most frequently used problem oriented coping strategies. On the other hand, the least frequently used affective oriented coping strategies were drink alcoholic beverages, take drugs, laughing, thinking that problems might be worse, blame someone else for your problem, relieve stress with meditation and physical activity, yoga and biofeedback. While do anything just to do something, let someone else solve the problem, set special goals aiding solving the situation and look at the problem objectively were the least frequently used problem oriented coping strategies. This result agrees with a study done in Egypt by (Saad, 2015) ${ }^{[30]}$ who found that the most frequently used affective oriented coping strategies were hoping that things will get better, search for help and comfort from friends and family. While speak with someone who has the same problem and draw on previous experience to aid you dealing with the problem, and accept the situation as it is were the most frequently used problem oriented coping strategies. 
The current study also revealed that, the least frequently used affective oriented coping strategies were take drugs, drink alcoholic beverages, and relieve stress with meditation and physical activity, while letting someone else solve the situation, waiting for the coming better things, and do anything just to do something were the least frequently used problem oriented coping strategies.

The previous studies showed that there were some inconsistent findings of the relationship between various coping strategies and caregiver burden. The current study found that there was negative significant correlation between caregiver burden and using of affective oriented and problem oriented coping strategies. This result supported by a study done in USA by Chen et al. (2018) ${ }^{[18]}$ who found that, problem-focused coping was negatively correlated with caregiver burden and a study done in Eastern Turkey by Dayapoğlu \& Tan (2017) ${ }^{[31]}$ who reported that, there was a negative correlation between the caregiver burden and total social support. This is may be related to that attention to the problem and focus on it can decrease caregiver burden but not supported by Tay et al. (2014) ${ }^{[32]}$ in Singapore who found no relation between the coping strategy and family burden scores.

\section{Conclusion}

Caregiver burden is moderate among family caregivers who care for elderly patients with end stage renal disease undergoing hemodialysis. Caregivers have been found to be using affective oriented coping strategies more than problem oriented coping strategies.

\section{Recommendations}

- Conduct effective in-service education and workshops in different aspects of caregiver health and its important as well as to update their knowledge for early identification of ill effects of caregivers.

- Educational programs to educate caregivers on effective coping strategies and encourage problem focused coping that will result in positive outcomes.

\section{References}

1. Abd Elhafeez, S., Bolignano, D., D’Arrigo, G., Dounousi, E., Tripepi, G. \& Zoccali, C. (2018). Prevalence and burden of chronic kidney disease among the general population and high-risk groups in Africa: a systematic review BMJ Open, 8(1):427 e015069. doi: 10.1136/bmjopen2016-015069

2. Ghonemy, T. A., Farag, S. E., Soliman, S. A., El-okely, A. \& Elhendy, Y. (2016). Epidemiology and risk factors of chronic kidney disease in the El-Sharkia Governorate, Egypt. Saudi J Kidney Dis Transpl,27(1):111117

3. Hamza, A. H. (2015). Epidemiological study of end stage renal disease (ESRD) patients on maintenance hemodialysis in Dakahlia governorate. Unpublished master thesis faculty of Medicine, Mansoura University

4. El-Zorkany, K. M. (2017). Maintenance hemodialysis in Menoufia governorate, Egypt: Is there any progress?. Journal of The Egyptian Society of Nephrology and Transplantation, 17(2):58-63

5. Marques, P. R., Botelho, R. M., Marcon, S. S. \& Pupulim, S. J. (2014). Coping strategies used by family members of individuals receiving hemodialysis. Text Context Nursing, 23(4): 915-24.

6. Shakya, D.,Tuladhar, J. \& Poudel, S.(2017). Burden and Depression among Caregivers of Hemodialysis 
Patients. Palliat Med Care, 4(1): 1-6 DOI: $10.15226 / 2374-8362 / 4 / 1 / 00131$

7. Mashayekhi, F., Pilevarzadeh, M., \& Rafati, F. (2015). The assessment of caregiver burden in caregivers of hemodialysis patients. Materia SocioMedica, 27(5), 333-336. http://doi.org/10.5455/msm.2015.27.3 33-336

8. Suri, R., Larive, B., Garg, A., Hall, Y., Pierratos, A., Chertow, G., Gorodetskeya, I., \& Kliger, A. (2011). Burden on caregivers as perceived by hemodialysis patients in the Frequent Hemodialysis Network (FHN) trials Nephrol Dial Transplant, 26: 23162322 doi: 10.1093/ndt/gfr007

9. Bolotova, K. \& Hachaturova, M. R. (2013). The role of time perspective in coping behavior, Psychology in Russia: State of the Art, 6(3): 121-122

10. Janghel, G. \& Shrivastav, P. (2017). Coping Behavior Assessment Scale (Indian Adaptation): Establishing Psychometrics Properties, The International Journal of Indian Psychology, 4(3):152

11. Zarit, S., Reever, K. \& Peterson, J. (1980). Relatives of the impaired elderly: correlates of feelings of burden. Gerontologist, 20(6):649-55.

12. Magdy, S. (2015). Relationship between Caregiving Burden and Psychological Health Status of Caregivers Caring for Older Adults with Cancer. Published Master Thesis, Faculty of Nursing, Mansoura University.

13. Abd El Meguid, A. (2000). Stressors and coping patterns of mothers of mentally handicapped children. Published Master Thesis, Faculty of Nursing, University of Alexandria.

14. Fadila, D. (2007). Coping behaviors of elderly patients with chronic obstructive pulmonary disease .published Master Thesis, Faculty of Nursing, University of Alexandria.

15. Jalowiec, A., \& Power, M. (1981). Stressors and coping in hypertensive and emergency room patients. Nurs Res, 30(1):10-15.

16. Subhashini, N., \& Indira, A. (2016). Assess the burden among caregivers of patients undergoing hemodialysis in tertiary care hospital Nellore. International Journal of Applied Research, 2(4): 559-561.

17. Cagan, O., Unsal, A., Celik, N., Yilmaz, A., Culha, I. \&Eren, H. (2018). Care Burden of Caregivers of Hemodialysis Patients and Related Factors. International Journal of Caring Sciences, 11 (1): 380-283

18. Chen, Y., Peng, Y., Xu, H., \& O'Brien, W. (2018). Age Differences in Stress and Coping: ProblemFocused Strategies Mediate the Relationship between Age and Positive Affect. The International Journal of Aging and Human Development, 86(4) 347-363

19. Abdallah, M., Baki, A., Hakim, S. \& Kamel, C. (2014). Epidemiological study of end stage renal disease at Ain Shams university hospital. A five year retrospective study. Life science Journal, 11(12): 1065

20. Abd Rabouh, M. (2017). Relationship between fatigue and functional status of the elderly patients on Hemodialysis. Un published Master thesis. Faculty of Nursing, Mansura University

21. Stanifer, J. W., Jing, B., Tolan, S., Helmke, N., Mukerjee, R., Naicker, S. \& Patel, U. (2014). The epidemiology of chronic kidney disease in SubSaharan Africa. A systematic review and meta-analysis. The lancet Global Health, 2(3):174-181 
22. El Shahed, A., Sharf, S., El Sebaee, H. \&Roshdy, M. (2013). Hemoglobin Level, Associated Co-Morbidities and quality of life among patients undergoing Hemodialysis at one of the university Hospitals in Cairo Governorate. World Applied Sciences Journal, 23(1):29-36

23. Mogharab, M., Hedayati, H., Najafi, R., Safari, M., Amiri, S. \&Adhami, S. (2011). prevelance of depression and life events in hemodialysis patients in Vali-Asr hospital in Birjand. Modern Care Journal, 8(3):125-134

24. El-Arbagy, A., Kora, M., El-Barbary, H., Gabr, H. \& Selim, A. (2015). Prevalence of End Stage Renal Disease in Menoufia Governorate. Nat Sci, 13(6):154-158.

25. Abd Elhafeez, N. (2014).The effect of implementing an instructional module on controlling adverse events of hemodialysis among patients with chronic renal failure. Un published Doctoral Thesis. Faculty of Nursing, Alexandria University.

26. Oyegbile, Y. \& Brysiewicz, P. (2017). Exploring caregiver burden experienced by family caregivers of patients with End-Stage Renal Disease in Nigeria. International Journal of Africa Nursing Sciences, 7: 136-143

27. Salama, R. \& Abou El-Soud, F. (2012). Caregiver burden from caring for impaired elderly: a cross-sectional study in rural Lower Egypt. Italian journal of public health, 9(4):3-6
28. Chindaprasirt, J., Limpawattana, P., Pakkaratho, P., Wirasorn, K., Sookprasert, A., Kongbunkiat, K. \& Sawanyawisuth, K. (2014). Burdens among Caregivers of Older Adults with Advanced Cancer and Risk Factors. Asian Pacific journal of cancer prevention, 15 (4): 1643-1648

29. Rodríguez-Pérez, M., Abreu-Sánchez, A., Rojas-Ocaña, M. J., \& del-PinoCasado, R. (2017). Coping strategies and quality of life in caregivers of dependent elderly relatives. Health and Quality of Life Outcomes, 15, 71. http://doi.org/10.1186/s12955-0170634-8

30. Saad, M., (2015). Coping behaviors and health related quality of life of elderly patients suffering from cancer. Un published master thesis. Faculty of Nursing, Mansura University

31. Dayapoğlu, N. \& Tan, M. (2017). The care burden and social support levels of caregivers of patients with multiple sclerosis. Kontakt, 19(1): 17-23

32. Tay, K. C, Seow, C. C., Xiao, C., Lee, H. M., Chiu, H. \& Chan, S. (2014). Structured interviews examining the burden, coping, selfefficacy, and quality of life among family caregivers of persons with dementia in Singapore. DementiaInternational Journal of Social Research and Practice, 15(2): 204220 